\title{
PENERAPAN MODEL PEMBELAJARAN MIND MAPPING TERHADAP KEMAMPUAN BERPIKIR KREATIF SISWA KELAS XI
}

\author{
Ummu Kalsum $^{1, a}$, Nur Aisyah Humairah ${ }^{2, b}$, Arini ${ }^{3, c}$ \\ 1,2,3Program Studi Pendidikan Fisika Universitas Sulawesi Barat \\ e-mail: ${ }^{a} U m m u . K a l s u m @ u n s u l b a r . a c . i d,{ }^{b}$ nuraisyah.humairah@unsulbar.ac.id, ${ }^{c}$ arini@ unsulbar.ac.id
}

\begin{abstract}
Abstrak
Penelitian ini bertujuan untuk mengetahui (1) kemampuan berpikir kreatif siswa sebelum dan setelah diterapkan model pembelajaran Mind mapping, (2) perbedaan yang signifikan antara kemampuan berpikir kreatif siswa sebelum dan setelah diterapkan model pembelajaran mind mapping. Jenis penelitian yang digunakan adalah pre-eksperimen dengan desain one-group-pretest-posttest. Populasi penelitian meliputi seluruh siswa kelas XI SMA Negeri 1 Pamboang. Sampel penelitian diambil dengan teknik purposive sampling, sebanyak 20 siswa. Teknik pengumpulan data menggunakan tes uraian (essay). Teknik analisis data menggunakan analisis deskriptif dan inferensial. Berdasarkan analisis deskriptif diperoleh skor rata-rata pretest sebesar 10,6 dan skor rata-rata posttest sebesar 21,7. Hasil analisis inferensial diketahui bahwa $t_{\text {hitung }}=17,518>t_{\text {tabel }}=2,093$ sehingga $H_{a}$ diterima. Dengan demikian dapat disimpulkan bahwa (1) kemampuan berpikir kreatif siswa sebelum diterapkan model pembelajaran mind mapping berada pada kriteria tidak kreatif dan setelah diterapkan berada pada kriteria kurang kreatif dan (2) terdapat perbedaan signifikan antara kemampuan berpikir kreatif siswa sebelum dan setelah diterapkan model pembelajaran mind mapping.
\end{abstract}

Kata kunci: Mind mapping, Kemampuan berpikir kreatif, Penelitian pre-eksperimen.

\section{IMPLEMENTATION OF MIND MAPPING LEARNING MODEL ON CREATIVE THINKING ABILITY OF STUDENTS OF CLASS XI}

\begin{abstract}
This research aims to know (1) the creative thinking ability of students before and after applied Mind mapping learning model (3) significant difference between the creative thinking ability of students before and after applied mind mapping learning. The research was pre-experiment research with onegroup-pretest-posttest design. Population in this research were all students of class XI MIPA SMA Negeri 1 Pamboang. The Sample was taken by purposive sampling technique, as many as 20 students. Data collection techniques was used test description (essay). The data analysis techniques was used descriptive and inferential analysis. The results of this research showed that the average pretest score of 10,6 and the posttest average score of 21,7. The result obtained $t_{\text {count }}=17.518>t_{\text {table }}=2.093$ then $H_{a}$ accepted. The result showed that (1) the creative thinking ability of students before applied Mind mapping learning model in criterion was not creative and after applied was less creative.(3) there was a significant difference between creative thinking ability of students before and after applied mind mapping learning model.
\end{abstract}

Keyword: Mind mapping, Creative thinking ability, Pre-experiment research.

\section{PENDAHULUAN}

Proses belajar pada diri pembelajar dimulai dari adanya pemberian stimulus untuk merangsang kemampuan kinerja otak dalam berpikir. Beragam kemampuan berpikir dari siswa yang dapat dilatih dalam pembelajaran di kelas. Salah satunya adalah kemampuan berpikir kreatif. Kemampuan berpikir kreatif siswa dalam pembelajaran fisika perlu mendapat perhatian khusus karena merupakan salah satu aspek dalam tujuan pendidikan [1].

Pada umumnya dalam pelajaran fisika di kelas siswa kurang mempunyai kemampuan untuk berpikir kreatif dalam menjawab soal yang diberikan. Fenomena ini diperkuat dari observasi yang dilakukan melalui memberikan tes kemampuan berpikir kreatif pada mata pelajaran Fisika. Bentuk tes yang diujikan berupa uraian (essay) yang terdiri dari 4 item 
soal. Hasil evaluasi tes menunjukkan bahwa keseluruhan $(100 \%)$ siswa kelas XI MIPA SMA Negeri 1 Pamboang tidak dapat memberikan jawaban atau cara selain yang terdapat dalam buku dan penjelasan dari gurunya. Hal ini tentunya mengindikasikan rendahnya kemampuan berpikir kreatif siswa pada mata pelajaran fisika.

Observasi lebih lanjut mengenai sisi berpikir kreatif diketahui bahwa penyebab lain rendahnya kemampuan kreatif siswa diantaranya (1) metode mengajar yang digunakan oleh guru tidak menekankan pada pemberian solusi lebih dari satu atas permasalahan yang diberikan. (2) teknik mencatat yang digunakan oleh siswa belum melatih sisi kreatif siswa. Dalam hal ini teknik mencatat yang digunakan oleh siswa berupa catatan biasa.

Oleh karena itu, untuk mengatasi permasalahan tersebut guru perlu memilih dan menerapkan model pembelajaran yang dapat melatih sisi kreatif siswa. Dalam merangsang kemampuan berpikir kreatif siswa, kegiatan pembelajaran harus membawa siswa dalam menjawab permasalahan dengan banyak cara dan kemungkinan jawaban yang benar sehingga dapat mengundang potensi intelektual serta kreativitas siswa dalam menemukan sesuatu yang baru. Model pembelajaran yang dimaksudkan yaitu model pembelajaran mind mapping. Model pembelajaran ini menciptakan suasana belajar yang baru sehingga guru tidak lagi menjadi pusat pembelajaran, melainkan berfokus pada keaktifan siswa. Selain itu, model pembelajaran mind mapping mampu melatih pengembangan kemampuan berpikir kreatif siswa serta mampu meningkatkan daya ingat siswa. Mind mapping merupakan teknik mencatat dan menulis yang kreatif. [2].

Kajian tentang keberhasilan model pembelajaran mind mapping telah dilakukan oleh [3] yang menyimpulkan bahwa skor ratarata yang diperoleh siswa pada kelas eksperimen dengan menggunakan model pembelajaran mind mapping berada pada kategori tinggi sedangkan skor rata-rata yang diperoleh siswa pada kelompok kontrol dengan menggunakan pembelajaran konvensional berada pada kategori sedang. Selain itu penelitian serupa dilakukan [4]. Hasil penelitiannya menunjukkan bahwa peningkatan kemampuan berpikir kreatif siswa SMP yang pembelajarannya menggunakan metode mind mapping lebih baik daripada metode biasa/konvensional.

Model pembelajaran mind mapping (peta pikiran) adalah model yang dirancang untuk membantu siswa dalam proses belajar untuk menyimpan informasi dan membantu menyusun inti-inti yang penting dari materi pelajaran ke dalam bentuk peta, grafik maupun penggunaan symbol. Akibatnya, siswa lebih mudah mengingat pelajaran tersebut [5].

Terdapat 6 langkah-langkah dalam proses pembelajaran Model pembelajaran mind mapping [6], yaitu:

(1) Guru menyampaikan tujuan pembelajaran

(2) Guru mengemukakan

konsep/permasalahan yang akan

ditanggapi oleh siswa dan sebaiknya permasalahan yang mempunyai alternatif jawaban.

(3) Membentuk kelompok siswa yang anggotanya 3-4 orang.

(4) Tiap kelompok mencatat alternatif jawaban hasil diskusi pada sebuah kertas dalam bentuk mind mapping.

(5) Tiap kelompok (atau diacak kelompok tertentu) mempresentasikan hasil diskusinya dalam bentuk mind mapping di depan kelas.

(6) Guru membimbing siswa membuat kesimpulan dari materi yang sedang berlangsung.

Ada beberapa kelebihan dari mind mapping [7], diantaranya adalah:

a) Membantu dalam merencanakan, berkomunikasi, lebih kreatif, memusatkan perhatian, menyelesaikan masalah, dan menghemat waktu karena dapat belajar lebih cepat.

b) Mengoptimalkan fungsi kerja otak kiri dan kanan secara penuh.

c) Paling awet menempel di memori otak kita.

d) Penggunaannya sangat luas, mulai dari anak sekolah sampai direktur, bahkan ibu rumah tangga juga dapat memanfaatkan teknik ini.

e) Apa pun materinya dapat dituangkan melalui mind mapping.

f) Bentuknya dapat ditulis tangan atau menggunakan software komputer.

Ada beberapa kelemahan dari Mind mapping [7], yaitu:

a) Memakan waktu yang lebih lama dalam pembuatan peta konsep dasar.

b) Bagi siswa yang tidak senang menggambar, mind mapping merupakan hal yang sukar. 
c) Ketidakmampuan untuk pembaca Mind mapping kurang mengerti yang dibuat orang lain.

Menurut Darusman [4] terdapat 4 Indikator Kemampuan Berpikir Kreatif siswa, seperti yang terlihat pada Tabel berikut ini.

Tabel 1. Indikator Kemampuan Berpikir Kreatif

\begin{tabular}{|c|c|}
\hline Pengertian & Perilaku \\
\hline $\begin{array}{l}\text { Berpikir lancar } \\
\text { (fluency) } \\
\text { Memberikan } \\
\text { banyak jawaban } \\
\text { atas pertanyaan } \\
\text { yang diberikan }\end{array}$ & $\begin{array}{c}\text { Menjawab dengan } \\
\text { sejumlah jawaban } \\
\text { jika ada } \\
\text { pertanyaan. }\end{array}$ \\
\hline $\begin{array}{l}\text { Berpikir luwes } \\
\text { (flexibility) } \\
\text { Memberikan } \\
\text { jawaban yang } \\
\text { bervariasi. }\end{array}$ & $\begin{array}{c}\text { Memberikan } \\
\text { bermacam-macam } \\
\text { penafsiran suatu } \\
\text { gambar,cerita atau } \\
\text { masalah }\end{array}$ \\
\hline $\begin{array}{l}\text { Berpikir } \\
\text { orisinal } \\
\text { (Originality) } \\
\text { Memberikan } \\
\text { jawaban secara } \\
\text { orisinil }\end{array}$ & $\begin{array}{c}\text { Memikirkan } \\
\text { masalah-masalah } \\
\text { atau hal yang tidak } \\
\text { terpikirkan orang } \\
\text { lain. }\end{array}$ \\
\hline $\begin{array}{c}\text { Berpikir Elaboras } \\
\text { (Elaboration) } \\
\text { Memberikan } \\
\text { jawaban yang } \\
\text { terperi. }\end{array}$ & $\begin{array}{l}\text { Mencari arti yang lebih } \\
\text { mendalam terhadap } \\
\text { jawaban atau pemecahan } \\
\text { detail-detail (bagian- } \\
\text { bagian) terhadap } \\
\text { gambarnya sendiri atau } \\
\text { gambar orang lain. }\end{array}$ \\
\hline
\end{tabular}

\section{METODE PENELITIAN}

Jenis penelitian yang digunakan dalam penelitian ini adalah penelitian pre-eksperimen yang menggunakan desain One-Group PretestPosttest sebagai berikut.

$$
\begin{array}{lll}
\mathbf{O}_{1} & \mathbf{X} & \mathbf{O}_{2}
\end{array}
$$

Keterangan:

X :Perlakuan (pembelajaran fisika dengan menerapkan model pembelajaran Mind mapping (peta pikiran)

$\mathrm{O}_{1} \quad$ :Pretest (pengukuran sebelum diberi perlakuan)

$\mathrm{O}_{2} \quad$ :Posttest (pengukuran setelah diberi perlakuan)

Populasi dalam penelitian ini adalah seluruh siswa kelas XI MIPA SMA Negeri 1 Pamboang tahun ajaran 2017/2018 yang berjumlah 74 orang.

\section{Validasi Instrumen}

Instrumen tes kemampuan berpikir kreatif yang disepakati sebelum digunakan akan dinilai oleh dua orang ahli dan hasil penilaian dari kedua ahli tersebut kemudian dianalisis dengan menggunakan validitas isi secara keseluruhan yang dikemukakan oleh Gregory. Koefisien validitas isi tersebut dihitung berdasarkan rumus berikut:

$$
\text { validitas isi }=\frac{D}{(A+B+C+D)}
$$

\section{Teknik Analisis Data}

Teknik analisis data yang digunakan dalam penelitian ini adalah analisis deskriptif dan analisis inferensial. Teknik analisis deskriptif digunakan untuk mendeskripsikan data penilaian model pembelajaran dan kemampuan berpikir kreatif siswa, sedangkan teknik analisis. inferensial digunakan untuk membuktikan hipotesis yang diajukan.

\section{Teknik Analisis Deskriptif \\ Penilaian Model Pembelajaran}

Analisis penilaian ini dimaksudkan untuk memberikan gambaran mengenai hasil pelaksanaan model yang digunakan dalam penelitian terhadap kemampuan berpikir kreatif siswa. Model yang digunakan adalah model pembelajaran Mind mapping. Untuk mengetahui nilai yang diperoleh, maka dapat digunakan rumus sebagai berikut:

$$
\text { Nilai }=\frac{\sum \text { penilaian tiap aspek }}{\sum \text { Aspek }}
$$

Kriteria penilaian model pembelajaran ditunjukkan pada tabel 2.

Tabel 2. Kriteria Penilaian Model Pembelajaran

\begin{tabular}{ll}
\hline Nilai & Kriteria \\
\hline 5 & Sangat Baik \\
4 & Baik \\
3 & Cukup Baik \\
2 & Kurang Baik \\
1 & Tidak Baik \\
\hline
\end{tabular}

\section{Penilaian Kemampuan Berpikir Kreatif}

Rumus yang digunakan dalam analisis deskriptif untuk penelitian ini adalah:

Skor Rata-Rata $(\underline{X})$ 


$$
\bar{X}=\frac{\sum f_{i} X_{i}}{\sum f_{i}}
$$

Standar Deviasi $\left(S_{d}\right)$

$$
S_{d}=\sqrt{\frac{\sum f_{i}\left(X_{i}-\bar{X}\right)^{2}}{n-1}}
$$

(Sugiyono, 2016:52) [13]

Untuk mengetahui nilai yang diperoleh siswa, maka skor diubah ke nilai dengan

$$
\begin{gathered}
\text { Nilai }= \\
\frac{\text { Total skor Kemampuan Berpikir Kreatif }}{\text { skor maksimun Kemampuan Berpikir Kreatif }} \\
100
\end{gathered}
$$

Adapun kriteria tingkat kemampuan berpikir kreatif dapat dilihat pada tabel sebagai berikut:

Tabel 3. Taraf Ketercapaian Kemampuan Berpikir Kreatif Siswa

\begin{tabular}{cc}
\hline $\begin{array}{c}\text { Keberhasilan } \\
\text { Tindakan }\end{array}$ & Kriteria \\
\hline $95 \leq \mathrm{PK} \leq 100$ & Sangat Kreatif \\
$80 \leq \mathrm{PK}<95$ & Kreatif \\
$65 \leq \mathrm{PK}<80$ & Cukup Kreatif \\
$55 \leq \mathrm{PK}<65$ & Kurang Kreatif \\
$\mathrm{PK}<55$ & Tidak kreatif \\
\hline
\end{tabular}

\section{Teknik Analisis Inferensial Uji Normalitas}

Pengujian normalitas dalam penelitian ini digunakan uji Chi-Kuadrat dengan. rumus [13] sebagai berikut:

$$
\chi^{2}=\sum_{\mathrm{i}=1}^{\mathrm{k}} \frac{\left(\mathrm{f}_{0}-\mathrm{f}_{\mathrm{e}}\right)^{2}}{\mathrm{f}_{\mathrm{e}}}
$$

Kriteria pengujian pada taraf signifikan $\alpha=$ 0,05 yaitu jika $\chi^{2}$ hitung $<\chi^{2}$ tabel, maka data terdistribusi normal. Jika $\chi^{2}$ hitung $\geq \chi^{2}$ tabel, maka data berdistribusi tidak normal. [13].

\section{Uji Hipotesis}

Uji hipotesis dilakukan untuk menjawab hipotesis penelitian. Adapun rumusan hipotesis yaitu sebagai berikut [15]

$$
\begin{aligned}
& H_{0}: \mu_{0}=\mu_{1} \\
& H_{a}: \mu_{0} \neq \mu_{1}
\end{aligned}
$$

Keterangan:

Ho : tidak terdapat perbedaan yang signifikan pada siswa kelas XI MIPA 1 SMA Negeri 1 Pamboang sebelum dan setelah diterapkan model pembelajaran Mind mapping (peta pikiran).

$\mathrm{Ha}$ : terdapat perbedaan yang signifikan pada siswa kelas XI MIPA 1 SMA Negeri 1 Pamboang yang signifikan sebelum dan setelah diterapkan model pembelajaran Mind mapping (peta pikiran).

$\mu_{o}$ : Skor rata-rata hasil kemampuan berpikir kreatif siswa kelas XI MIPA SMA Negeri 1 Pamboang sebelum diterapkan model pembelajaran Mind mapping (Peta Pikiran).

$\mu_{1}$ : Skor rata-rata hasil kemampuan berpikir kreatif siswa kelas XI MIPA SMA Negeri 1 Pamboang setelah diterapkan model pembelajaran Mind mapping (Peta Pikiran).

Kriteria data diperoleh dari populasi yang berdistribusi normal maka untuk pengujian hipotesis digunakan statistik t, dengan $\alpha=$ 0,05 [16] yaitu:

$$
\mathrm{t}=\frac{\mathrm{Md}}{\sqrt{\frac{\sum x d^{2}}{N(N-1)}}}
$$

Kriteria pengujian untuk uji $\mathrm{t}$ adalah[7] sebagai berikut:

$t_{\text {hitung }} \leq t_{\text {tabel }}$, maka $\mathrm{H}_{0}$ diterima

$t_{\text {hitung }}>t_{\text {tabel }}$, maka $\mathrm{H}_{\mathrm{a}}$ diterima.

\section{HASIL DAN DISKUSI \\ Hasil Analisis Deskriptif \\ Penilaian Model Pembelajaran}

Tabel 4. Hasil Analisis Penilaian

Keterlaksanaan Model Pembelajaran

\begin{tabular}{cc}
\hline Nilai & Kriteria \\
\hline 4 & Baik \\
4 & Baik \\
4 & Baik \\
4 & Baik \\
4 & Baik \\
\hline
\end{tabular}

Pada Tabel 4 menunjukkan bahwa nilai keterlaksanaan penerapan model pembelajaran yang diperoleh pada pertemuan ke 2, ke 3, dan ke 4 dan ke 5 memenuhi kategori baik. Penilaian Kemampuan Berpikir Kreatif. Berdasarkan hasil analisis diperoleh data berikut : 
Tabel 5. Kategori Kemampuan Berpikir Kreatif Siswa Sebelum diterapkan Model Pembelajaran Mind Mapping (Peta Pikiran)

\begin{tabular}{cccc}
\hline \multirow{2}{*}{$\begin{array}{c}\text { Keberhasilan } \\
\text { Tindakan }\end{array}$} & Kriteria & \multicolumn{2}{c}{ Pretest } \\
\cline { 3 - 4 } & & $\begin{array}{c}\text { Frekuensi } \\
(\boldsymbol{f})\end{array}$ & $\begin{array}{c}\text { Persentase } \\
(\boldsymbol{\%})\end{array}$ \\
\hline $95 \leq \mathrm{PK} \leq 100$ & Sangat Kreatif & 0 & 0 \\
$80 \leq \mathrm{PK}<95$ & Kreatif & 0 & 0 \\
$65 \leq \mathrm{PK}<80$ & Cukup Kreatif & 0 & 0 \\
$55 \leq \mathrm{PK}<65$ & Kurang kreatif & 0 & 0 \\
$\mathrm{PK}<55$ & Tidak kreatif & 20 & 100 \\
\hline Jumlah & & 20 & 100 \\
\hline
\end{tabular}

Tabel 6. Kategori Kemampuan Berpikir Kreatif Siswa setelah diterapkan Model Pembelajaran Mind Mapping (Peta Pikiran)

\begin{tabular}{cccc}
\hline \multirow{2}{*}{$\begin{array}{c}\text { Keberhasilan } \\
\text { Tindakan }\end{array}$} & Kriteria & \multicolumn{2}{c}{ Posttest } \\
\cline { 3 - 4 } & & $\begin{array}{c}\text { Frekuensi } \\
(\boldsymbol{f})\end{array}$ & $\begin{array}{c}\text { Persentase } \\
(\boldsymbol{\%})\end{array}$ \\
\hline $95 \leq \mathrm{PK} \leq 100$ & Sangat Kreatif & 0 & 0 \\
$80 \leq \mathrm{PK}<95$ & Kreatif & 0 & 0 \\
$65 \leq \mathrm{PK}<80$ & Cukup Kreatif & 7 & 35 \\
$55 \leq \mathrm{PK}<65$ & Kurang kreatif & 11 & 50 \\
$\mathrm{PK}<55$ & Tidak kreatif & 3 & 15 \\
\hline Jumlah & & 20 & 100 \\
\hline
\end{tabular}

\section{Hasil Analisis Inferensial Uji Normalitas}

Hasil pengujian normalitas data skor kemampuan berpikir kreatif siswa sebelum diterapkan model pembelajaran Mind mapping menunjukkan bahwa $\chi^{2}$ hitung $=6,938<\chi^{2}$ tabel $=$ 9,488 dengan $d k=(\mathrm{k}-1)$ pada taraf signifikan $\alpha$ $=0,05$. Hal ini berarti data tersebut berdistribusi normal. Sedangkan data posttest $\chi^{2}$ hitung $=5,149$ $<\chi^{2}$ Tabel $=9,488$ yang bermakna data tersebut juga berdistribusi normal.

\section{Uji Hipotesis}

Pengujian hipotesis statistik yang digunakan adalah uji-t dengan kriteria :

$\mathrm{t}_{\text {hitung }} \leq \mathrm{t}_{\text {tabel }}$, maka $\mathrm{H}_{0}$ diterima

$t_{\text {hitung }}>\mathrm{t}_{\text {tabel }}$, maka $\mathrm{H}_{\mathrm{a}}$ diterima

Hasil perhitungan dengan menggunakan uji-t pada taraf signifikan $\alpha=0,05$ diperoleh harga $t_{\text {hitung }}=17,981$ dan harga $t_{\text {tabel }}=2,045$, yang berarti $t_{\text {hitung }}>t_{\text {tabel }}$. Hasil bermakna bahwa terdapat perbedaan signifikan antara kemampuan berpikir kreatif siswa kelas XI MIPA SMA Negeri 1 Pamboang sebelum dan setelah diterapkan model pembelajaran mind mapping.
Berdasarkan tabel 5, kemampuan berpikir kreatif untuk pretest menunjukkan bahwa seluruh siswa memiliki hasil pretest dibawah nilai $<55$ yang berada pada kriteria tidak kreatif dengan persentase $100 \%$. Rendahnya nilai hasil tes kemampuan berpikir kreatif siswa dipengaruhi oleh beberapa faktor, yaitu (1) model pembelajaran guru kurang melatih sisi kreatif siswa. Guru hanya menggunakan satu solusi dalam pemecahan soal. Akibatnya, siswa kurang terlatih dalam mengembangkan kemampuan berpikirnya yakni berpikir kreatif. (4) bentuk catatan siswa yang monoton dan kurang menarik sehingga siswa cenderung malas untuk mempelajari kembali materi yang dipelajari di sekolah. Akibatnya, berdampak pada nilai kemampuan berpikir kreatifnya.

Setelah perlakuan menunjukkan adanya peningkatan kemampuan berpikir kreatif siswa yang ditunjukkan pada tabel 6 . Meningkatnya skor kemampuan berpikir kreatif siswa setelah diterapkan model pembelajaran Mind Mapping (peta pikiran) dipengaruhi adanya pemberian tugas yang melatih kemampuan berpikir kreatif siswa seperti membuat Mind Mapping. Teknik mencatat dengan Mind Mapping dapat membiasakan siswa memberikan solusi 
pemecahan masalah lebih dari satu jawaban. Selain itu, Mind Mapping merangsang kerja otak kanan dan otak kiri secara sinergis melalui penggunaan warna, simbol, teks, gambar pada catatan. Pada dasarnya otak kreatif adalah otak kiri dan otak kanan bekerja secara sinergis. [17]. Dengan demikian, melalui pencapaian kesinergisan kerja kedua belah otak dapat meningkatkan kemampuan berpikir kreatif siswa. Hal inilah yang memberikan peluang peningkatan skor pada posttest.

\section{SIMPULAN DAN SARAN Simpulan}

Kemampuan berpikir kreatif siswa kelas XI MIPA SMA Negeri 1 Pamboang sebelum diterapkan model pembelajaran Mind mapping (Peta Pikiran) berada pada kriteria tidak kreatif dan setelah diterapkan berada kriteria kurang kreatif Terdapat perbedaan signifikan antara hasil kemampuan berpikir kreatif siswa kelas XI MIPA SMA Negeri 1 Pamboang sebelum dan setelah diterapkan model pembelajaran Mind mapping (Peta Pikiran).

\section{Saran}

Sebaiknya siswa ditekankan sebelum memasuki kelas untuk menyediakan alat pewarna untuk setiap siswa agar keterbatasan alat pewarna yang untuk membuat mind mapping dapat diminimalisir. Ada baiknya siswa ditugaskan untuk mempelajari materi yang akan dipelajari pada pertemuan berikutnya agar dalam waktu yang digunakan untuk membuat Mind mapping di kelas lebih efisien.

\section{DAFTAR PUSTAKA}

[1] Priantini dewa. 2013. Pengaruh Metode Mind mapping Terhadap Keterampilan Berpikir Kreatif dan Prestasi Belajar IPS. e-journal Program Pascasarjana Universitas Pendidikan Ganesha. Vol.3.

[2] Buzan, Tony. 2012. Buku Pintar Mind Map. Jakarta: PT Gramedia Pustaka Utama.

[3] Sunarman, dkk. 2015. Model Pembelajaran Mind mapping Berpengaruh Terhadap Hasil Belajar Matematika Siswa Kelas V SD Gugus 2 Luwus-Mekarsari. e-Journal PGSD Universitas Pendidikan Ganesha Vol.3. No.1.

[4] Darusman, Rijal. 2014. Penerapan Metode Mind mapping (Peta Pikiran)
Untuk Meningkatkan Kemampuan Berpikir Kreatif Matematik Siswa SMA. Jurnal ilmiah program studi matematika STKIP siliwangi. Vol 3 No.2.

[5] Syam, Natriani dan Ramlah. 2015. Penerapan Model Pembelajaran Mind mapping Dalam Meningkatkan Hasil Belajar Pada Mata Pelajaran Ilmu Pengetahuan Sosial Siswa Kelas IV SDN 54 Kota Parepare. Jurnal Publikasi Pendidikan. Vol 5 No. 3. 2088-2092.

[6] Taniredja dkk. 2015. Model-model Pembelajaran Inovatif dan Efektif. Bandung : Alfabeta

[7] Siregar. 2014. Penggunaan Metode Mind mapping terhadap Prestasi Belajar Siswa. JURNAL Pengabdian Kepada Masyarakat Vol. 20 No.75.

[8] Sugiyono. 2015.Metode Penelitian Pendidikan Pendekatan Kuantitatif, Kualitatif, dan $R \& D$. Bandung: Alfabeta.

[9] Retnawati, Heri. 2016. Analisis Kuantitatif Instrumen Penelitian. Yogyakarta: Parama Publishing.

[10] Ibrahim, M. 2005. Assesmen Berkelanjutan. Surabaya: Unipress Unesa.

[11] Arsyad, Arie Arma. 2015. Pengembangan Perangkat Pembelajaran Berorientasikan Model Cooperative Problem Solving Pada Pokok Bahasan Optik Untuk Meningkatkan Hasil Belajar Siswa SMP (Tesis Tidak Dipublikasikan). Surabaya: Universitas Negeri Surabaya

[12] Ali dan Khaeruddin. 2012. Evaluasi Pembelajaran. Makassar: Badan Penerbit Universitas Negeri Makassar.

[13] Sugiyono. 2016. Statistika Untuk Penelitian. Bandung : Alfabeta.

[14] Firdaus, dkk. 2016. Meningkatkan Kemampuan Berpikir Kreatif Matematis Siswa SMA Melalui Pembelajaran OpenEnded Pada Materi SLPDV. Jurnal pendidikan. Vol. 1.No.2. 227-236.

[15] Susetyo, Budi. 2017. Statistika untuk Analisis Data Penelitian. Bandung: Refika Aditama.

[16] Arikunto, Suharsimi. 2014. Prosedur Penelitian Suatu Pendekatan Praktek. Jakarta: Rineka Cipta.

[17] Hernowo, 2008. Menjadi Guru Yang Mau dan Mampu Mengajar secara Menyenangkan. Bandung : PT. Mizan Media Utama. 